\title{
New Cold War and the Crisis of the Liberal Global Order
}

\author{
Greg SIMONS \\ PhD, University of Canterbury, New Zealand \\ Associated Researcher at the Diplomatic Academy of the Ministry of Foreign Affairs of \\ the Russian Federation; Associate Professor in Political Science \\ Uppsala, University in Sweden, IRES, Box 514, SE-751 20 Uppsala, Sweden \\ E-mail: gregmons@yahoo.com \\ ORCID: 0000-0002-6111-5325
}

\section{Marina A. KUKARTSEVA}

Marina Glaser (Kukartseva)

Doctor of Political Philosophy, Professor

Faculty of World Economy and World Politics, Department of International Relations National Research University Higher School of Economics, 101000, Myasnitskaya St., 20, Moscow, Russian Federation

E-mail: mkukartseva@gmail.com

ORCID: 0000-0002-7069-4779

CITATION: Simons G., Kukartseva M.A. (2019) New Cold War and the Crisis of the Liberal Global Order. Outlines of Global Transformations: Politics, Economics, Law, vol. 12, no 3, pp. 77-93. DOI: 10.23932/2542-0240-2019-12-3-77-93

Received: 22.01.2019.

\begin{abstract}
Currently, international relations and the global order are in turmoil and disorder. The bases of the international order and the means by which it was regulated are in the process of being dismantled, such as the central considerations of the Treaty of Westphalia that guided international politics and diplomacy for centuries. As the world becomes increasingly polarised into different opposing and competing geopolitical camps, the question needs to be asked, why is this happening? The answer seems to lie, at least in part, in a rapidly evolving and changing system of global political hegemony, where liberal democracy is on the wane. This is also further influenced by the declining economic and military power of the West, where the US is still the unipolar hegemony, but
\end{abstract}

is declining in its hard power and ability to manage/control international affairs as it was able to do in the 1990s (such as the First Gulf War in 1990-91 and Kosovo in 1999). This paper analyses the rise and decline of the West, and the international consequences and results. A conclusion of this paper, although the West is significantly weakened in terms of its political, military and economic power, it is trying to stave off its decline. Therefore, the 'New Cold War' is an important element in this strategy as a means to try and unite a divided and wary domestic audience by attempting to invoke the spectre of a foreign 'threat' and to do this through the concept of a crisis. A crisis represents an extraordinary situation, which if accepted, becomes the basis for applying extraordinary mea- 
sures to 'rescue' the public from the hazard. It is a means to try and bargain the public's freedom for their sense of security.

KEY WORDS: New Cold War, international relations, Russia, United States, diplomacy, geopolitics, global liberalism, hegemony

\section{Introduction}

The global liberal order has been guided by sets of norms and values (individual freedoms, multi-culturalism and globalisation), messianic and expansionist (seeking to 'convert' non-liberal democracies by force or attraction), and financially and militarily upheld by the United States. The end of the Cold War in the early 1990s, which was brought about by the collapse of the Soviet Union in 1991, saw the end of the decades long bipolar global order that influenced international relations through two very different ideological and cultural visions of the organisation of society. This was greeted with enthusiasm and a moment of great potential for a new human future, such as Francis Fukuyama's declaration of the 'end of history'. However, simultaneously others saw this crucial point in human history in another light and one of victory and defeat. That of the victory of capitalism and liberal democracy, which had 'defeated' communism ... and to the victors go the spoils. After almost three decades as the unipolar hegemony, the United States and liberal democracy are facing a crisis and a struggle for not only their global hegemony, ${ }^{1}$ but also for their continued existence. This change of fortunes is reflected over time in how inter- national relations are managed by significant actors.

Not so long ago in recent history, perhaps not more than 10 years ago, there was no talk of a New Cold War. But in the last five years, especially, there has been a greater level of consensus on the existence of a New Cold War. The various underlying reasons, and who is to blame for the situation, have been disputed. But in order to understand the current situation, there is a need to go back in history to a point in time when international relations were very different, where the world witnessed the emergence of a bipolar world order - the Soviet Union and the United States. There were two very different systems and visions of an ideal vision of society, and the collapse of this system in 1991, which saw the rise of a unipolar world international order.

This paper seeks to understand the current crisis in international relations, the tensions between the West and Russia, through understanding and analysing the massive changes taking place in terms of the crisis of liberal democracy and the emergence of a New Cold War. Of particular interest is the role and significance of the concept of a "crisis" and how it can be operationalised in the context of international relations, especially the potential to constrain and restrain the foreign policy options of an opponent/competitor. There is a clear role and use of an emotional logic, which employs the use of values and norms in international relations, which has replaced the system of rational logic and an understanding of national interest. As such, the international system is much more volatile and unpredictable, creating an environment of increased risks and hazard.

\footnotetext{
1 For the purposes of this paper, hegemony is understood as a specific form of domination of international affairs by a state that uses its advantages possessed in resources and power to set the rules for the world order and to influence other states, by attraction or coercion, to conform to those rules and interests of the dominant state.
} 
Background: Creation of the Liberal Global Order

The global liberal order was founded upon notions of values and norms in an understanding of the way the international order was managed, and not upon sets of national interests and realist priorities. Pax Britannica of the $19^{\text {th }}$ century can be considered as embodying the notions of free trade and creating sets of rules to promote national interest, the creation of the League of Nations in the wake of World War One can be considered an attempt to further systematise and codify the global order in favour of Western hegemony. The global liberal order was re-established at the end of the Second World War with Bretton Woods Agreement, and initially it did deliver economic prosperity and political freedoms. However, from the 1970s it has been shaken by oil shocks and economic crises, which has led to increasing calls for change. ${ }^{2}$ Until relatively recently, it was assumed and taken on faith that there was no alternative to the global liberal order, and there was a convergence of countries such as China and Russia into this system. ${ }^{3}$ Before the current times of trouble, the origins of the concept and practice were based upon a common humanitarian vision.

The basic tenants of liberalism revolved around the idea of global individual and economic freedoms, and a world that was guided by cooperative values and norms.
[...] all humans share some core experiences, values and interests, and that no human group is inherently superior to all others. Cooperation is therefore more sensible than conflict. All humans should work together to protect their common values and advance their common interests. And the best way to foster such cooperation is to ease the movement of ideas, goods, money and people across the globe. ${ }^{4}$

On a superficial level of taking these eloquent words and desires at face value, there is a somewhat utopian world vision. There are those that defend liberalism as being neither a myth nor an accident, but as a conscious and deliberate desire to reshape world politics during the emergence of the Cold War between the US-led world and the Soviet-led world. ${ }^{5}$ Those who support liberalism claim that it is responsible for the long period of relative peace in the Western world, and that it is the primary driving factor for the US engagement in global affairs. However, a realist interpretation of the 70 years of relative peace is not owed to the presence of a political ideology, but rather the calculations and risks of a very dangerous nuclear balance of power between the US and Soviet Union. ${ }^{6}$ Therefore, the perception and actions were not based on value and norm based assertions and projections of justice, but rather prudent action that is required to ensure the interests and survival of mankind.

\footnotetext{
2 Guillén M. (2019) The Demise of the Global Liberal Order. IISS, January 17, 2019. Available at: https://www.iiss.org/blogs/ survival-blog/2019/01/demise-of-the-global-liberal-order; Tocci N. (2018) The Demise of the International Liberal Order and the Future of the European Project. Istituto Affari Internazionali, November 19, 2018. Available at: https://www.iai.it/en/pubblicazioni/ demise-international-liberal-order-and-future-european-project, accessed 30.06.2019.

3 Wright T. (2018) The Return to Great-Power Rivalry Was Inevitable. The Atlantic, September 12, 2018. Available at: https:// www.theatlantic.com/international/archive/2018/09/liberal-international-order-free-world-trump-authoritarianism/569881/, accessed 30.06.2019.

4 Harari Y.N. (2018) We Need a Post-Liberal Order Now. The Economist, November 26, 2018. Available at: https://www.economist. com/open-future/2018/09/26/we-need-a-post-liberal-order-now, accessed 30.06.2019.

5 Mazarr M.J. (2018) The Real History of the Liberal Order: Neither Myth Nor Accident. Foreign Affairs, August 7, 2018. Available at: https://www.foreignaffairs.com/articles/2018-08-07/real-history-liberal-order, accessed 30.06.2019.

6 Allison G. (2018) The Truth About the Liberal Order: Why it Didn't Make the Modern World. Foreign Affairs, August 28, 2018. Available at: https://www.foreignaffairs.com/articles/2018-08-28/truth-about-liberal-order, accessed 30.06.2019.
} 
As global trends and processes saw the eventual collapse of the bipolar world of the old Cold War, and the United States and global liberalism emerge as the new global hegemony, liberalism embarked upon a much more expansionist and messianic path in international relations. One concrete example and illustration of this is the creation of the notion of 'liberal peace.' This is the value based assumption that liberal democracies do not go to war against one another, but the threatening aspect was that this was used as a justification for using pre-emptive military force against what are labelled as non-democracies. This was characterised as an inevitable process in a truly Orwellian understanding (war as peace) of fostering democracy with the use of hard military force against the 'opponents of democracy'.

This was accompanied by the dropping of long standing means of regulating the use of military force through the use of Just War theory, which requires weighing and balancing interests and outcomes of the application of military force. It simply took too long to articulate reasonable and logical arguments for the coming "humanitarian" wars. Instead, the expedient justification was found in vague emotional and value-based mechanisms as the Responsibility to Protect (R2P). In 2011, the first application of the R2P concept against Libya amply demonstrated the superiority of using more realist forms of logic and argumentation. This is the problem at the international level, domestic problems also follow a similar pattern of lack of transparency and accountability, and a demand for faith in the system.
Liberal democracy is also being undermined by a tendency to emphasize "liberal" at the expense of "democracy." In this kind of politics, rulers are insulated from democratic accountability by a panoply of restraints that limit the range of policies they can deliver. Bureaucratic bodies, autonomous regulators, and independent courts set policies, or they are imposed from outside by the rules of the global economy.

In his new and important book The People vs. Democracy, the political theorist Yascha Mounk calls this type of regime - in apt symmetry with illiberal democracy - "undemocratic liberalism". He notes that our political regimes have long stopped functioning like liberal democracies and increasingly look like undemocratic liberalism. ${ }^{7}$

Liberal democracy began as a movement based on the notion of individual freedoms and rights, where liberal democracy as a number of individual nation states creates a network of states around a powerful hegemonic state that forms the concept of global liberal democracy. However, it has gradually evolved into a brand label, but something that it was established in opposition to where group consensus is enforced, and it is neither liberal nor democratic in nature. An individual that deviates from the official and mainstream liberal narrative runs the risk of being ostracized, being subjected to character assassination, including being asserted as agent of the named other. It is very much on the defensive and facing an increasingly assertive challenge by so-called populist forces, which occurs at the very same time as a discernible shift in power and influence in international relations.

\footnotetext{
7 Rodrik D. (2018) The Double Threat to Liberal Democracy. Project Syndicate, February 13, 2018. Available at: https://www. project-syndicate.org/commentary/double-threat-to-liberal-democracy-by-dani-rodrik-2018-02?barrier=accesspaylog, accessed 30.06.2019.
} 


\section{A Crisis and its Significance in International Relations}

The crisis in international relations is owed in large part to the decline of the Western and liberal global hegemony. There has been a steadily increasing amount of commentary on the prospects and a Western decline and what this may mean for the system of international relations. In a 2012 article in The Atlantic, that there is a steady decline in the economic and military might of the West, the US in particular. It also noted, there is the influence of self-inflicted harm that has been born from strategic complacency and significant foreign policy errors of judgement (for example, Iraq in 2003 and Libya in 2011). ${ }^{8}$ The global hegemony of the West has rested for decades upon the soft power of liberalism and the hard power of US military might. Both of these aspects have been weakened significantly following the end of the old Cold War to the point where more commentators are invoking the use of the concept of crisis.

This requires further inquiry with two interrelated questions, what is a crisis, and why is it significant to invoke one at this moment in time? A crisis is generally considered as being an extra-ordinary event, a situation and condition that breaks the normal routine and functioning of society [Boin, t'Hart, Stern, Sundelius 2005]. The term "crisis" is often invoked in the public sphere, often it is not clearly defined what exactly is meant and what is entailed. From a theoretical perspective, a crisis can be defined as being present when three simultaneously present aspects can be found. 1) A threat to values, which can involve a threat to hu- man life, property, the economy, state integrity and many other examples. 2) The element of uncertainty is present, the shortage of reliable information and the often rapid pace of events make the ability to predict what is going to happen next very difficult, which can raise the perceived levels of risk and threat being faced. 3) Time constraint is the final part of the puzzle, which is in connection to the simple calculation that the longer a crisis event continues the more damage is done, which necessitates a rapid resolution in order to ensure a speedier and effective recovery process in the road back to 'normality' [Boin, t'Hart, Stern, Sundelius 2005, pp. 2-4]. It is important to distinguish between the tangible (physical) elements of a crisis and the intangible elements (psychological, including perception and opinion).

A crisis is not only a period of a heightened sense of risk and threat, but it is also a highly symbolic and politically charged event. When it comes to understanding what societal values are at stake, these become readily apparent in the communication around a crisis. "These values tend to be broadly defined societal values such as security, safety, economic development, democratic legitimacy, environmental protection, and so on" [Nohstedt 2011, p. 201]. Value expectations are based upon notions and understandings of socially imposed rules or norms, interpretations of law and regulations, national and international mandates, and public expectations/ opinion.

One of the important implications and effects of a crisis, when the concept is evoked, it signals a period of an extraordinary situation and this permit the invoker to introduce extraordinary mea- 
sures that may otherwise be unacceptable to an affected society. Crises can be selectively used to shape instruments to enable greater leeway for an actor in the event of a crisis. "Crisis evaluations might contribute to institutionalise moral standards into formal rules or codes of conduct" [Nohstedt 2011, p. 201]. This owes, at least in part, to a crisis event precipitates a political call for action that is nominally and rhetorically meant to resolve the crisis at hand. This is intended to offer a specific situational logic, sometimes a false one, which is intended to prime and mobilise the intended audience to consent to the suggestion in order to alleviate the psychological discomfort that may be experienced by the audience within the communicated framework of humanitarian dilemmas. How does this relate to the system of international relations?

Contemporary tensions and strains in international relations were not always present. Some two to three decades ago was a period of optimism, and the continued expansion of global liberalism's influence. In the 1990s and early 2000s, the Western and international communities became practically synonymous. The United States and their closest partners have quite confidently controlled the agenda of the leading international institutions. Due to the fact that this control has recently failed the community could act and completely bypass these institutions. At the same time, the story began with the attempts to include Russia in the Western international community. Cooperation with it was considered to be a strategic partnership. From the point of view of the West, Russia must be westernized, which means its political culture has to be reformed according to the Western normative vision of politics as "the highest guiding moral power". The most important part of Western project was the further spreading of the western liberal norms of political and social life. Without it, the West was not ready to see Russia as an equal partner [Lukin 2016, pp. 93-97]. The process of "Westernisation" of Russia was stopped after Vladimir Putin came to power after 2000, even though he initially followed a Western global liberal course via Russia's integration in to the World Trade Organisation and the G7. However, the continued one-sided power relationship caused a reconsideration of the value and consideration of Russia's national interests being replaced by vague value and norm based sets of rules and conduct that in effect rendered Russia to be an object of international relations rather than a subject of it.

From the perspective of the official Russian understanding and perspective of the current state of international relations, and more specifically the relations between Russia and the West, a number of important points are emerging. These issues were raised in 2007 with the presentation of President Putin's well-known speech at a conference on international security in Munich. A further event the Georgia-Ossetia conflict of 2008 have consistently worsened relations. The issue of Crimea reintegration with Russia in 2014 forced Russia to make a choice between conflict and capitulation. As soon as the choice was made in favor of the conflict, the discussion about Russia's integration into the West became completely meaningless. Russia and the West are facing this reality with a growing gap between them.

Russia is not interested in dialogue from the standpoint of absolute non-alternative neo-liberal ideas. In terms of the national character, Russia traditionally is patriarchal, masculine conservative military state, where the army is considered as being one of the most important parts of this political body. That's why the position of the West is nowadays regarded by the Russian elite as being unacceptable. Russian representation of politics is in almost complete contradiction with the ambitions of 
the West to transform the world according to liberal ideas

In security matters, there is movement from the issues of local conflicts resolution, international terrorism, proliferation of nuclear weapon and disarmament, illicit drug trafficking and other types of trans-border crime to scenarios of an armed conflict between Russia and NATO. It is one again become the political reality, the parties started strengthening military capabilities along the NATO-Russian confrontation lines and engaged in the regular demonstration of power (including the flights of strategic bombers and missile launchers). ${ }^{9}$

The formal position of the West differs considerably from the Russian perspective. Many Western countries have undertaken a principally critical stance on Russian politics. Sometimes the statements coming from the West are not bordering on the theatrical, for example, the many calls for the people to prepare to resist in case of Russia's invasion. ${ }^{10}$ Given the history of a number of states, if they really feared an attack from Russia, their statements would be more conciliatory. For two generations, the Cold War has played a systemic role for Western political elites and ideological propaganda.

From one side, this is understandable: the rejection of military intervention in Europe and especially the annexation of territories forms part of the international political identity of the EU after World War II. The leading political forces in the European Union clearly follow a pro-Atlantic orientation. Some of them, however, attempt to maintain balance in their foreign policy stance such as Berlin, which is ready to maintain a dialogue with Moscow, but not deviating from the principles and relying on the solidarity of the EU and NATO countries. However, the West needs to understand that the more it demonizes Russia with arguments about annexation, aggression, occupation, the further on it will move away from Russia.

By severely criticizing Moscow's actions, whilst being perceived as not acting in accordance with its words (such as the illegal presence of US troops in Syria), it is important not to burn the bridges in the end and not to give up the dialogue with it at all. The 'war' is going on because Russia rejects the very idea of being dominated and requires being treated as an equal with other global actors. Russia does not favor making concessions under pressure - both external and internal. The institutional matrix of Russian nation-building is foreign policy sovereignty and the ability to be self-protected on its own - Putin-Russia either will be sovereign or it will not exist at all. Other players on a world political arena do not want to admit it and try to force Russia compromise its integrity.

It seems from a Russian perspective that the West wants Russia to repeat the fate of the late Soviet Union and to commit what is in effect suicide. However, the various risks: local, regional and global, associated with the regime change in Moscow, are huge. Today's political elites in Russia are not the same as they were some 15 years ago, just like the Russian siloviki and they are unlikely to voluntarily agree to collective political suicide. However, while severely criticizing Moscow's actions, it is important not to burn the bridges in the end and not to give up dialogue completely. If now we still admit that the glass is still half full, we need to

9 Arbatov A. Nuclea Arms Control: Ways To Overcome A Comprehensive Crises // Russia : Arms Control, Disarmament and International Security. Moscow, IMEMO RAN, 2016. pp. 18, 22

10 Peck M. (2018) Russia Could Invade the Baltics with 845,000 Troops (But What Happens Next?). National Interest, January 2, 2018. Available at: https://nationalinterest.org/blog/the-buzz/russia-could-invade-the-baltics-845000-troops-what-happens-23894, accessed 30.06.2019. 
look for ways to move forward, and then we need to understand major contemporary security issues:

1. There are certain things that need to be done together. For instance, fight against terrorism

2. To restore the atmosphere of mutual trust in the military cooperation.

The intensification of confrontation between Russia and the West can lead to the remilitarization of Europe, the spillover of the conflict to new regions (such as the Arctic) and even "nuclear chaos." The expansion of NATO and the approach of the alliance to the Russian borders is a factor that doesn't have only military consequences. It violates the principle of indivisibility of security and aggravates misunderstanding between Russia and Europe.

The Russian government positions its country as an autonomous Eurasian pole of power in a multi-centred world, possessing a special geopolitical orientation both European and Asian. The main factor determining Russia's behavior is that it now feels less like the periphery of Europe and more like the independent center of Eurasia. In this situation, the idea of absence of alternative in the cooperation between the EU and Russia is not imperative anymore.

Russia is suggesting the concept of 'Great Eurasia.' Russia is open to constructive cooperation with all partners. And Russia is ready to cooperate in the volume to which her partners agree. From the West these volumes are small, and from the other countries of the UN they are huge. The unity of the Western community is no longer an axiom, although it is unlikely to see the erosion of the community of the West and its institutions. Most likely, there will be a readjustment of relations within this community. The current global context of the debate on the challenge to US global hegemony predicts a possible transition from unipolarity to multipolarity.
The basis for hegemony is economic strength that translates into a dominant influence in global trade and finance. Maintenance of the capitalist world-economy in a form that benefits the hegemonic power requires, at times, military force [Flint 2017, p. 220].

Flint's understanding of hegemony is based mostly upon the notion of hard power, which is easier to measure, and tends to neglect the soft power effect that is also important. It is important as this enables opportunities to be accomplished on the basis of positive relationship dynamics and therefore the absence of sufficient means to coerce an actor. Hard power is more easily understood and seen owing to its tangible and rational form and presence, and soft power can be overlooked owing to its intangible and often more emotionally inclined form. The above takes the form of creating alternative and competing institutions of hegemony, such as G20, BRICS, SCO, One Belt One Road and the Eurasian Economic Union that challenge the US and Western dominated institutions. This forms the basis of a number of geopolitical and geo-economic tensions between the US-led West with China and Russia.

Right now, the transatlantic allies have come close to the line, after which their relationship will never be the same. At the same time, the United States still remains the dominant partner in this connection. The US engages with the minimum of duties and responsibilities, but insistently demands absolute commitment from its partners. The economies of countries that are seen to trade and cooperate with opponents of the United States may be impacted through economic sanctions. In the case of Russia, it is first of all, actively implementing joint projects with energy and manufacturing countries of the European Union, for example Germany and the Gazprom pipelines. The situation of growing tensions in international relations has re- 
sulted in some observers referring to and invoking the notion of the global affairs entering an era of a New Cold War.

\section{Emergence of a New Cold War}

At this stage, it should be duly noted that Russia and the West or even the United States should not be understood as being monolithic entities with an absolute lack of diversity of thought, opinion and interests. For example, recent elections and referendums held in the United Kingdom, Netherlands, Italy and the United States have revealed cracks in the liberal 'consensus' through the emergence of a block of anti-political establishment forces. This has increased the internal dimensions of the conflict that is now being openly fought, such as the Mueller Report or the conflict within the Trump administration on the question of the future of NATO or the maintaining troops illegally in Syria or not. This adds an additional layer to the already complex and strained system of international relations.

Origins of what has come to be known as the New Cold War have their origins at the end of the old Cold War, which saw the US enter the system of international relations as the unipolar power. Such an abrupt end of a stable, but risky era of a bipolar world order, created a brief window of opportunity that was greeted with enthusiasm. However, the United States treated the end of the Cold War more as a victory, rather than an opportunity.

But the Cold War as an ideological struggle disappeared only in part, despite Communism's implosion. On the American side, not so much had changed on that day (dissolution of the Soviet Union in December
1991). The Cold War was over, and the United States had won it. But most Americans still believed that they could only be safe if the world looked more like their own country and of the world's governments abided by the will of the United States. ${ }^{11}$

According to the author of the New York Times opinion piece, the United States sought to capitalise on its advantage offered by the Soviet collapse and impose its will upon other countries in a manner that stressed power projection, territorial control and regime change. Fast forward until the end of the first decade of the $21^{\text {st }}$ century, when Western hard power is visibly on the wane, and the attraction of liberal democracy is rapidly being eroded and a completely new global hierarchy seemed to be in the making [Flockhart 2016]. As a consequence, a lively debate has been gradually developing in academia as to whether a New Cold War exists or not. This is of course a matter of perspective and opinion, although there are dangers inherent in applying a brand association from a historical geopolitical event to the present day. Having given this caveat, there is growing consensus that a New Cold War does in fact exist.

A significant problem in an objective definition is derived from the very highly politicised nature of the current global crisis, where narratives and knowledge production are used by the competing sides to bestow legitimacy upon their causes and to erode the perceived legitimacy of their opponents. Research on the 'old' Cold War has created a solid research basis from which to start the inquiry. Some tentative research has been noted from earlier than the earlier stated spring 2014, concerning the prospects of a 'new' Cold War has been published. In 2008, Richard Sakwa pub-

11 Westad O.A. (2017) The Cold War and America's Delusion of Victory, Opinion. The New York Times, August 28, 2017. Available at: https://www.nytimes.com/2017/08/28/opinion/cold-war-american-soviet-victory.html?ref=opinion\&_r=0, accessed 30.06.2019. 
lished a paper on the debate concerning the dynamics of Russian foreign policy and the 'regime question' (concerning Vladimir Putin's rule). Sakwa contends that Cold War patterns of thinking began to emerge in connection to the discussion of Russia and its role in the world. For example, Richard Shirreff and Maciej Olex-Szczytowski's report Arming for Deterrence: How Poland and NATO Should Counter a Resurgent Russia from 2015 that assumes Russia's hostile military intent against the West based upon notions of opposing sets of norms and values. The report goes as far as to categorically state that "Russia has thus become the most serious geopolitical and military threat to NATO" (page 1). This characterisation very much fits the characterisation of a possible 'new' Cold War based on the premises of the 'old' Cold War. The end of the 'old' Cold War saw the US military as being put in an awkward position in terms of its assumed opponent, which was understood as a mass army based on the Warsaw Pact. However, it soon found itself on unfamiliar grounds in getting caught in various insurgencies, which it has not proved particularly well suited for in either doctrine or tactics. The possible emergence of a 'new' Cold War would place it on much more familiar grounds with a conventional state-based opponent. There are many subjective assumptions and assessments involved among those that advocate a 'new' Cold War has begun.

Russia's annexation of Crimea, invasion of Donbas, and continued threats to Ukraine and other European countries not only menace the stability of the post-Cold War order in Europe, but also pose a fundamental challenge to the assumptions about the strategic environment that have undergirded the
NATO alliance for the past quarter of a century [Kroenig 2015, p. 49].

It is evident in this text, the use of fear, ${ }^{12}$ which is being used as a means to shape public opinion and perception to this new crisis. The logic used to reach such conclusions, by many concerned, is a path of understanding one's own security and interests objectives. However this is often done without understanding the other actor's sets of security and interest objectives, the information and knowledge available to them in reaching the policy and strategy decisions that are made. Therefore, it is critical to understand not only what drives the 'us' side, but also the equivalent factors that influence the 'other.' The main case study used in the 'new' Cold War research involves the scenario of Russia against the West (NATO and the European Union in particular). However, other Cold War scenarios do exist, such as in the Middle East [Gause 2014], as a result of Obama's 'Asia Pivot' [Ross 2012], Latin America and other geopolitical hotspots.

Even though the West characterises itself as offering a better quality of life, economic opportunity and military might, the means of communication implies a certain level of weakness in their position. There is an attempt to mask this through trying to project a binary world of ethical stance and legitimacy, rather than more concrete and tangible as well as measureable facets. The quantity and quality of mainstream framing of the 'crisis' of the New Cold War is important for being able to judge the cues and likely 'remedies' that are to be offered by liberal democracy in order to 'protect' themselves from the project threat. This is where the notion and use of moral panic is critical to understand.

12 Fear can be effective when two simultaneous psychological elements are present and resonate in the target audience: 1) the belief something bad can happen, in this case implied military threats from Russia; and 2) those Russian military threats can be experienced by them, hence the threat is on an unspecified wider level of "other European countries". 
The idea of a moral panic is that it is a mechanism of creating change through manipulating perception and opinion. Its origin as "a concept was first used by Stanley Cohen in 1973 to describe orchestrated and mass mediated public campaigns aimed at generating fear of visibly identified 'folk devils"' [Franklin, Hamer, Hanna, Kinsey, Richardson 2011, p. 152]. This is not to say that a moral panic is necessarily something that is tangible, but rather the promise of a risk or threat. Moral panics are intended to serve as a means to enable a change in law, policy or current practices, which is justified as being necessary to "protect" the public and the common good [Franklin, Hamer, Hanna, Kinsey, Richardson 2011, p. 152; Krinsky 2013, pp. 1-2]. As noted by Simons and Sumskaya (2018), moral panics may also be used as a catalyst for other tasks, such as political regulation. This is to be understood as creating an environment of fear and caution in which the inhabitants are compliant to the will and the needs of the hegemonic political power.

Moral panic's operationalisation connects to the political dimensions of the crisis that is encapsulated within the idea of the New Cold War, which is precipitated by the decline of Western power ${ }^{13}$ and global hegemony and the attempts to stave off this scenario. The tit-for-tat sanctions between the US and EU versus Russia have caused both sides to become increasingly fatigued with each other at a time when the channels of communication between them are becoming increasingly restricted and political calls for a tougher stance on the other are gaining pace.

If there is one thing that the overwhelming majority of policymakers and experts in Moscow and Washington now agree on is that the current crisis is that the current crisis in US-Russia relations is spiralling in its character, systemic in its nature and lingering in its resolution prospects. The rest of the discourse is ripped between narratives of who's to blame for what and interpretations on just how reasonable the US sanctions are or asymmetric Russia's response is. ${ }^{14}$

There are an increasing number of stories appearing in the media that are documenting the gradually increasing tensions in Europe, which emphasize a narrative of the Cold War. The New York Times ran a headline in August 2017 - US Troops Train in Eastern Europe to Echoes of the Cold War ${ }^{15}$ or in Reuters a headline Russia: Pence Balkans Comments Expose Washington's Cold War Ideology. ${ }^{16}$ Warnings have begun to appear in mainstream media headlines, such as the Washington Post's We're on the Road to a New Cold War. ${ }^{17}$ Others have resisted referring to the situation of the confrontation (in particu-

\footnotetext{
13 This decline has even been more recently openly admitted in high level government reports from leading Western countries, such as the United Kingdom's parliamentary report on Libya (Libya: Examination of Intervention and Collapse and the UK's Future Policy Options: Government Response to the Committee's Third Report of Session 2016-17 (2016). House of Commons. Foreign Affairs Committee. Available at: https://publications.parliament.uk/pa/cm201617/cmselect/cmfaff/834/834.pdf, accessed 30.06.2019).

14 Suchkov M.A. (2017) What the Sanctions Really Mean for Russia. National Interest, August 6, 2017. Available at: http:// nationalinterest.org/feature/what-the-sanctions-really-mean-russia-21804, accessed 30.06.2019.

15 Schmitt E. (2017) US Troops Train in Eastern Europe to Echoes of the Cold War. The New York Times, August 6, 2017. Available at: https://www.nytimes.com/2017/08/06/world/europe/russia-america-military-exercise-trump-putin.html?mcubz=1, accessed 30.06.2019.

16 Vasiljevic S. (2017) Russia: Pence Balkans Comments Expose Washington's Cold War Ideology. Reuters, August 3, 2017. Available at: https://www.reuters.com/article/us-russia-usa-pence-idUSKBN1AJ2L1, accessed 30.06.2019.

17 We're on the Road to a New Cold War (2017). The Washington Post, July 31, 2017. Available at: https://www.washingtonpost. com/opinions/were-on-the-road-to-a-new-cold-war/2017/07/31/213af6be-7617-11e7-8839-ec48ec4cae25_story.html?utm_ term $=.8574$ e2962235, accessed 30.06.2019.
} 
lar originating in the wake of Euromaidan and Crimea) between the West and Russia as a 'new' Cold War, yet still categorising Russia and the West as adversaries [Legvold 2014]. There are other voices that say there is no doubt that a 'new' Cold War is under way.

Henry Kissinger one of the most prominent geopolitical thinkers from the United States for the last decades states that there is a 'new' Cold War and that part of the blame rests with the West and its lack of willingness to take non-western actors security and national interests in to account. The result he claims has been an imbalance in international relations, which is exacerbated by the West not being "honest" with itself. ${ }^{18}$ Zbigniew Brzezinski another prominent geopolitical thinker also assessed that a 'new' Cold War had begun, referencing the point in time in line with the events in Ukraine and Crimea in particular. Although he did not see the situation as a threat as Kissinger did, but rather a positive sign that the world was 'standing up to' Russia. ${ }^{19}$ However, what has been described here is only one relatively small part of a much larger and more complex series of events and processes in the global crisis.

The New Cold War is much more complex and risky than the old Cold War. In part this is owing to the growing influence of multipolarity in international affairs as opposed to the more stable and predictable bipolarity of the old Cold War. There is still one superpower, rising international powers (such as China and Russia), and regional powers (such as Iran, Saudi Arabia and India), in addition to the multitude of lesser powers. Furthermore, the West is operationalising value and normative based projections, rather than concrete in- terests and certainties. Therefore, the situation arises when one side uses emotion as logic and the other uses a rational approach. Furthermore, even though the West is in decline, it is still for now the hegemonic power and this produces an environment of asymmetry in the military and economic power balance in relation to the rising global powers. Even though there are visible signs of decline, it is a gradual process that may take some time before the unipolar hegemonic global order evolves tangibly into something else. The US dollar still continues to be the global currency, US military spending is massive and greater than all other countries in alliance and opposition, and US financial markets are still dominant. Therefore, some aspects of US global hegemony are more robust and resilient than others. From a Russian perspective, the US is currently entrenched in are harming its strategic interests and capacities.

Finally, the US has adopted a new ideology of global polarisation and division, presenting Russia and China in the most recent National Security Strategy and other influential documents as a kind of united authoritarian bloc of revisionist powers committed to undermining the existing international order and opposing the free world. This aims to unite allies and partners under US leadership and win a global confrontation for the second time [Karaganov, Suslov 2018].

This is seen in the on again and offagain trade war with China, the economic sanctions against Russia and a continual cycle of armed conflict. In the wake of the Arab Spring there has been a lot of turmoil in the Middle East and North Africa,

\footnotetext{
18 von Mittelstaedt J., Follath E. (2014) "Do We Achieve World Order Through Chaos or Insight?". Spiegel Online, November 13, 2014. Available at: http://www.spiegel.de/international/world/interview-with-henry-kissinger-on-state-of-global-politicsa-1002073.html, accessed 30.06.2019.

19 Fischer S., Stark H. (2015) "We Are Already in a Cold War". Spiegel Online, July 2, 2015. Available at: http://www.spiegel.de/ international/world/interview-with-zbigniew-brzezinski-on-russia-and-ukraine-a-1041795.html, accessed 30.06.2019.
} 
which has become even more complicated lately with the dispute between Saudi Arabia and Qatar. This is in addition to the USled Global War On Terrorism (GWOT) that has been ongoing since 2001, with no end in sight. The Asia Pivot initiated by President Obama has led to an increase in tensions between the US and China, which is very evident in the South China Sea currently. There has also be an increase in tensions and competition between different actors in South America, where although the Monroe Doctrine predominates the GWOT distracted US attention that permitted other actors to take hold. The recent threat of the possible use of military force by the US on Venezuela may signal a return. The border clashes between India and China, the changing geopolitical alliances among India, Pakistan, Russia and the United States, plus the prospects of war with North Korea, all signal an increasing unpredictable and volatile world of increasing risks and threats. Any one of the above mentioned tensions and conflicts can potentially transform from cold to hot at a moment's notice. How these different processes and events are narrated and perceived by the different sides needs to be understood, not from a single perspective, but multiple perspectives, which is something that is greatly lacking today.

\section{Conclusion}

It is evident that the world is on the way towards a new global order, the decline of US military and economic power and the erosion of liberal democracy's appeal as it is unable to meet the demands and expectations of its own civil human security and interests (for example, falling living standards and increasing crime). This decline has enabled and encouraged other regional and global powers to emerge and begin to challenge the assumptions and premises of the 'old' post-Cold War international order. These challenges have been greatly aided and assisted by the various strategic and operational mistakes that have been made by the West, which has decimated its soft power, and is continuing to significantly weaken its military and economic power. The Global War On Terrorism has cost over US $\$ 5$ trillion and the incidence of terrorism has increased $6500 \% !^{20}$ Ultimately, the operational results of waging foreign policy by values and norms are a highly costly pursuit that ignores concrete interests, which result in working against self-interest and security. The current period of moral panic that surrounds the crises of the New Cold War and the 'populist' challenge to liberal democracy is an emotional and politically symbolic reaction to this decline. It leaves no room for genuine dialogue or possibility of arriving at a compromise in this zero sum game, which is based on a defensive information war stance, and not an offensive one. The moral panic phase of the New Cold War signals not only a distraction for the Western publics, but also a last ditch attempt to retain the initiative in international relations, which seems to be all but lost.

What will prevail, the logic of confrontation or the logic of cooperation? Actually, it is the question of political will of the opposing sides. Despite the fact that Moscow is ready for possible cooperation, a sober calculation shows that one cannot expect to improve relations with the West, at least not in the short to medium term.

20 Costs of War (n/y). Watson Institute of International and Public Affairs, Brown University. Available at: https://watson.brown. edu/costsofwar/figures; The US War On Terror Has Cost \$5 Trillion And Increased Terrorism by 6,500\% (2016). CS Globe the World Online, September 19, 2016. Available at: http://csglobe.com/the-us-war-on-terror-has-cost-5-trillion-and-increased-terrorismby-6500/, accessed 30.06.2019. 
Russia suggests introducing a new paradigm of relations with the West, the paradigm of rational partnership and not of unilateral submission to Western dictates that demand change and concessions from only one party. What will prevail, the logic of confrontation or the logic of cooperation? The logic of rationality and interests in international relations is currently replaced with emotion and values.

The current global liberal order is under great strain and pressure from a number of crises and weaknesses. Although the decline is noticeable in some aspects, the evolution from a unipolar world order may take many years or even decades before it happens. This is dependent not only on the actions of the opponents, but also the efficacy of the response by the US and the West to the internal and external challenges that they face. There seems to be a growing consensus that the world is witnessing a gradual evolution from a unipolar world order of the United States to a much more complex multi-polar non-Western world order of different sized and strength powers.

\section{References}

Boin A., t'Hart P., Stern E., Sundelius B. (2005) The Politics of Crisis Management: Public Leadership Under Pressure, New York: Cambridge University Press.

Coombs W.T. (2014) Applied Crisis Communication and Crisis Management: Cases and Exercises, Thousand Oaks (CA): Sage.

Flint C. (2017) Introduction to Geopolitics, $3^{\text {rd }}$ Edition, London: Routledge.

Flockhart T. (2016) The Coming Multi-Order World. Contemporary Security Policy, vol. 37, no 1, pp. 3-30. DOI: 10.1080/13523260.2016.1150053

Franklin B., Hamer M., Hanna M., Kinsey M., Richardson J.E. (2011) Key Concepts in Journalism Studies, London: Sage.

Gause III, F.G. (2014) Beyond Sectarianism: The New Middle East Cold
War. Brookings Doha Centre Analysis Paper. No. 11, July 2014. Available at: https://oaktrust.library.tamu.edu/ bitstream/handle/1969.1/166935/ New_MiddleEast_ColdWar.pdf?sequence $=1 \&$ is Allowed $=y, \quad$ accessed 30.06.2019.

Karaganov S., Suslov D. (2018) A New World Order: A View From Russia. Russia in Global Affairs, October 4, 2018. Available at: https://eng.globalaffairs.ru/ pubcol/A-new-world-order-A-view-fromRussia--19782, accessed 30.06.2019.

Krinsky C. (2013) The Ashgate Research Companion to Moral Panics, Farnham: Ashgate.

Kroenig M. (2015) Facing Reality: Getting NATO Ready for a New Cold War. Survival, vol. 57, no 1, pp. 49-70. DOI: 10.1080/00396338.2015.1008295

Legvold R. (2014) Managing the New Cold War: What Moscow and Washington Can Learn From the Last One. Foreign Affairs, vol. 93, no 4, pp. 74-84. Available at: https://heinonline.org/HOL/LandingPage?handle $=$ hein.journals/fora93\&div= 88\&id $=$ \&page $=\& \mathrm{t}=1560665273$, accessed 30.06.2019.

Lukin A. (2016) Russia in a Post-Bipolar World. Survival, vol. 58, no 1, pp. 91-112. DOI: 10.1080/00396338.2016.1142141

Nohrstedt D. (2011) Uncertainty, Accountability, and the Conduct of Post-Crisis Inquiries. Ethics and Crisis Management (ed. Svedin L.), Charlotte (NC): Information Age Publishing, pp. 199-216.

Ross R.S. (2012) The Problem with the Pivot: Obama's New Asia Policy is Unnecessary and Counterproductive. Foreign Affairs, vol. 91, no 6, pp. 70-82. Available at: https://www.foreignaffairs.com/articles/ asia/2012-11-01/problem-pivot, accessed 30.06.2019.

Sakwa R. (2008) 'New Cold War' or Twenty Years' Crisis? Russia and International Politics. International Affairs, vol. 84, no 2, pp. 241-267. DOI: 10.1111/j.14682346.2008.00702.x 
Shirreff R., Olex-Szczytowski M. (2015) Arming for Deterrence: How Poland and NATO Should Counter a Resurgent Russia, Washington DC: Atlantic Council.

Simons G. Sumskaya A. (2018) The Concept of "Moral Panic" in the Present Medi- areality of Russia and West: Experience of Perception from the Position of Communicative Cultural Memory. Znak, vol. 29, no 3, pp. 184-196. Available at: http://journals. csu.ru/index.php/znak/article/view/62/26, accessed 30.06.2019 (in Russian).

\section{Новая холодная война и кризис либерального глобального порядка}

\section{Грег САЙМОНС}

$\mathrm{PhD}$, Университет Кентербери, Новая Зеландия

научный сотрудник, Дипломатическая академия Министерства иностранных дел Российской Федерации

доцент по политическим наукам, Уппсала, University in Sweden, IRES, Box 514, SE-751 20 Uppsala, Швеция

E-mail: gregmons@yahoo.com

ORCID: 0000-0002-6111-5325

\section{Марина Алексеевна КУКАРЦЕВА}

Марина Гласер (Кукарцева)

доктор философских наук, профессор, факультет мировой экономики и мировой политики, Департамент международных отношений

Национальный исследовательский университет «Высшая школа экономики», 101000, ул. Мясницкая, д. 20, Москва, Российская Федерация

E-mail: mkukartseva@gmail.com

ORCID:

ЦИТИРОВАНИЕ: Simons G., Kukartseva M.А. (2019) New Cold War and the Crisis of the Liberal Global Order. Outlines of Global Transformations: Politics, Economics, Law, vol. 12, no 3, pp. 77-93. DOI: 10.23932/2542-0240-2019-12-3-77-93

Статья поступила в редакцию 22.01.2019.

АННОТАЦИЯ. В настоящее время международные отношения и мировой порядок находятся в смятении и беспорядке. Происходит демонтаж основ международного порядка и средств, с помощью которых он регулировался, например, основных положений Вестфальского договора, который веками направлял международную политику и дипломатию. По мере того как мир все больше распадается на различные противостоящие и конкурирующие геополитические тагеря, возникает вопрос: почему это происходит? Ответ, по-видимому, лежит, по крайней мере частично, в быстро развивающейся и меняющейся системе глобальной политической гегемонии, где либеральная демократия развивается по нисходящей траектории. $\mathrm{Ha}$ 
это оказывает влияние и сокращение экономической и военной мощи Запада, где США по-прежнему сохраняют однополярную гегемонию, однако их способность, как это было в 1990-х гг., управлять ходом международных дел и контролировать его снижается. В данной статье анализируются подъем и упадок Запада, а также международные последствия и результаmы этого проиесса. Авторы статьи приходят к выводу, что, хотя политическая, военная и экономическая мощь Запада значительно ослаблена, он пытается приостановить ее дальнейший упадок. Поэтому «новая холодная война» является важным элементом этой стратегии как попытка объединить разделенное и встревоженное общественное мнение с помощьью призрака иностранной «угрозы» и з кониепиии кризиса. Кризис представляет собой чрезвычайную ситуацию, которая, если ее принять, становится основой для применения чрезвычайных мер по "спасению" населения от опасности. Это попьтка обменять свободу на чувство безопасности.

КЛЮЧЕВЫЕ СЛОВА: новая холодная война, международные отношения, Россия, Соединеннье Iтмать, дипломатия, геополитика, глобальный либерализм, гегемония

\section{Список литературы}

Сумская А.С., Саймонс Г.Д. (2018) Концепция «моральной паники» в современной медиареальности России и Запада: опыт восприятия с позиции коммуникативно-культурной памяти // Знак. Т. 29. № 3. С. 184-196 // http://journals.csu.ru/index.php/znak/ article/view/62/26, дата обращения 30.06.2019.
Boin A., t'Hart P., Stern E., Sundelius B. (2005) The Politics of Crisis Management: Public Leadership Under Pressure, New York: Cambridge University Press.

Coombs W.T. (2014) Applied Crisis Communication and Crisis Management: Cases and Exercises, Thousand Oaks (CA): Sage.

Flint C. (2017) Introduction to Geopolitics, $3^{\text {rd }}$ Edition, London: Routledge.

Flockhart T. (2016) The Coming Multi-Order World // Contemporary Security Policy, vol. 37, no 1, pp. 3-30. DOI: 10.1080/13523260.2016.1150053

Franklin B., Hamer M., Hanna M., Kinsey M., Richardson J.E. (2011) Key Concepts in Journalism Studies, London: Sage.

Gause III, F.G. (2014) Beyond Sectarianism: The New Middle East Cold War // Brookings Doha Centre Analysis Paper. No. 11, July 2014 // https://oaktrust.library.tamu.edu/bitstream/handle/1969.1/166935/New_MiddleEast_ ColdWar.pdf? sequence $=1$ \&isAllowed $=y$, дата обращения 30.06.2019.

Karaganov S., Suslov D. (2018) A New World Order: A View From Russia // Russia in Global Affairs, October 4, 2018 // https://eng.globalaffairs.ru/pubcol/Anew-world-order-A-view-from-Russia--19782, дата обращения 30.06.2019.

Krinsky C. (2013) The Ashgate Research Companion to Moral Panics, Farnham: Ashgate.

Kroenig M. (2015) Facing Reality: Getting NATO Ready for a New Cold War // Survival, vol. 57, no 1, pp. 49-70. DOI: 10.1080/00396338.2015.1008295

Legvold R. (2014) Managing the New Cold War: What Moscow and Washington Can Learn From the Last One // Foreign Affairs, vol. 93, no 4, pp. 74-84// https://heinonline.org/HOL/LandingPage? handle $=$ hein.journals $/$ fora93 $\&$ div $=88$ $\& \mathrm{id}=\&$ page $=\& \mathrm{t}=1560665273$, дата обращения 30.06.2019. 
Lukin A. (2016) Russia in a Post-Bipolar World // Survival, vol. 58, no 1, pp. 91112.DOI: $10.1080 / 00396338.2016 .1142141$

Nohrstedt D. (2011) Uncertainty, Accountability, and the Conduct of Post-Crisis Inquiries // Ethics and Crisis Management (ed. Svedin L.), Charlotte (NC): Information Age Publishing, pp. 199-216.

Ross R.S. (2012) The Problem with the Pivot: Obama's New Asia Policy is Unnecessary and Counterproductive // Foreign Affairs, vol. 91, no 6, pp. 70-82 // https://www.foreignaffairs.com/articles/ asia/2012-11-01/problem-pivot, дата обращения 30.06.2019.

Sakwa R. (2008) 'New Cold War' or Twenty Years' Crisis? Russia and International Politics // International Affairs, vol. 84, no 2, pp. 241-267. DOI: $10.1111 /$ j.1468-2346.2008.00702.x

Shirreff R., Olex-Szczytowski M. (2015) Arming for Deterrence: How Poland and NATO Should Counter a Resurgent Russia, Washington DC: Atlantic Council. 